Received 23.10.2018

Reviewed 16.11 .2018

Accepted 03.12.2018

A - study design

B - data collection

C - statistical analysis

D - data interpretation

E - manuscript preparation

F - literature search

\title{
Role of drainage layer on green roofs in limiting the runoff of rainwater from urbanized areas
}

\author{
Anna M. BARYLA ${ }^{\text {ABCDEF } \bowtie}$
}

orcid.org/0000-0002-9895-2741; Warsaw University of Life Sciences, Faculty of Civil and Environmental Engineering, Nowoursynowska 166,02-787 Warszawa, Poland; e-mail: anna_baryla@sggw.pl

For citation: Baryła A.M. 2019. Role of drainage layer on green roofs in limiting the runoff of rainwater from urbanized areas. Journal of Water and Land Development. No. 41 (IV-VI) p. 12-18. DOI: 10.2478/jwld-2019-0022.

\begin{abstract}
Green roofs play a significant role in sustainable drainage systems. They form absorbent surfaces for rainwater, which they retain with the aid of profile and plants. Such roofs therefore take an active part in improving the climatic conditions of a city and, more broadly, the water balance of urbanized areas. One of the factors influencing the hydrological efficiency of green roofs is the drainage layer. In the article, column studies were carried out under field conditions involving the comparison of the retention abilities of two aggregates serving as the drainage layer of green roofs, i.e. Leca ${ }^{\circledR}$ and quartzite grit. The average retention of the substrate was $48 \%$; for a $5 \mathrm{~cm}$ drainage layer of Leca ${ }^{\circledR}$ retention was $57 \%$, for a $10 \mathrm{~cm}$ layer of Leca average retention was $61 \%$. For a $5 \mathrm{~cm}$ layer of quartzite grit average retention was $50 \%$, for $10 \mathrm{~cm}$ layer of quartzite grit $53 \%$. The highest retention was obtained for the column with the substrate and 10-centimeter layer of Leca ${ }^{\circledR}$. At the same time, it was shown that Leca ${ }^{\circledR}$ is a better retention material than quartzite grit. The initial state of substrate moisture content from a green roof appears to be a significant factor in reducing rainfall runoff from a green roof; the obtained values of initial moisture content made for a higher correlation than the antecedent dry weather period.
\end{abstract}

Key words: drainage layer, green roof, retention, runoff, substrates

\section{INTRODUCTION}

The progressing development of cities is changing natural areas into impermeable surfaces, leading to a change in the hydrological cycle [ATALLAH et al. 2018; BARSZCZ 2016; BERNDTSSON 2010; MROWIEC, SOBCZYK 2014; ROMANIAK 2017]. Moreover, the aging infrastructure in cities, urbanization rate and climate change, by the degraded hydrological cycle, may constitute a threat to urban drainage. Sustainable urban drainage systems constructed in the USA, Germany, Netherlands [BOAS BERG et al. 2017; KOHLER 2006; PALlA et al. 2010; WONG, JIM 2015], may serve as alternative strategies for urban planning and rainwater management in urbanized areas [BARYŁA et al. 2018a; STOVIN et al. 2012; SzULCZEWSKA at el. 2014]. These systems copy the relationships taking place between a natural catchment, returning the imbalanced proportions between the processes of retention, infil- tration, transpirations and decontamination with the use of plants. Green roofs play a significant role in sustainable drainage systems [BARYŁA et al. 2018b; BUS et al. 2016; PALLA et al. 2010; PĘCZKOWSKI et al. 2018; SOBCZYK, Mrowiec 2016; VillarReAL, BENGTSSON 2005]. In addition to hydrological abilities, green roofs decrease the effect of urban heat islands [WONG, JIM 2015], decrease energy usage by cooling the roof in the summer period [BANTING et al. 2017], create a habitat for plants and animals, thus improving urban biodiversity [CATALANO et al. 2018; EMILSSON et al. 2007; KÖHLER 2006], improve the aesthetics of cities [BENGTSSON et al. 2005; STOVIN et al. 2012; SzOTA et al. 2017]. The environmental benefits stemming from the construction of green roofs outweigh their limitations, such as the high costs of capital and conservation, supporting the use of these solutions in urbanized areas. Construction-wise, green roofs are multi-layer structures where each of the layers plays an important part 
in the structure and contributes to the whole [BUFFAM et al. 2016; MoRgAn et al. 2013; ZHANG, GUO 2013]. Traditionally, a drainage layer, the purpose of which is to retain water for plants and safely drain away its excess to the drainage system, is located above the layer of hydroinsulation and protective layer. The next layer in the system is the filtration layer, protecting the layers beneath against the penetration of small particles of suspensions washed away with rainwater from the roof substrates. The surface part of green roofs comprises the layer of substrate along with the vegetation growing on it. All layers above the hydro-insulation can influence rainwater retention values. In the case of the drainage layer, mineral drainage of aggregates does well to fulfil the role of storing and draining water. Single-fraction mineral aggregates (with the exception of limestones and crushed concrete), as well as light artificial aggregates (e.g. LWA-light weigh aggregate) can be used as drainage. Loose powdery materials containing lime should not be applied due to the negative influence on drainage devices over the course of their use [DAFA 2015]. An advantage of aggregate-based drainage is the possibility of flexibly adjusting the depth of the layer as well as creating counter-slopes in the structure. Due to the better possibilities of condensing and ensuring plant roots an additional supply of water, it is advisable to apply crushed aggregates. The binding guidelines for mineral aggregates for drainage are PN-EN 13242, whereas for light aggregates - PN-EN 13055. In addition to mineral aggregates, the drainage layer can be made of profiled artificial aggregates or geosynthetics [DAFA 2015]. When selecting the drainage layer, materials that are not harmful to the environment and plants, as well as being compatible with other materials and resistant to the effects of atmospheric factors ought to be selected [DAFA 2015]. The drainage selection criteria are very broad. Firstly, the loading possibilities of the structure ought to be assessed, since aggregate-based drainage systems significantly load the structure The weight of a 5-centimeter layer of drainage made of aggregate saturated with water is anywhere from $30 \mathrm{~kg} \cdot \mathrm{m}^{-2}$ (crushed kermesite) to $90 \mathrm{~kg} \cdot \mathrm{m}^{-2}$ in the case of natural aggregates [Laboratorium Dachów Zielonych undated]. Drainage systems made of synthetics do not weigh much, even together with the stored water, i.e. from 0.3 to
$25 \mathrm{~kg} \cdot \mathrm{m}^{-2}$. Another criterion is the compression strength; aggregate-based drainage always reveals a high or very high value of this parameter. This is not so in the case of synthetic drainages, as their compression strength is strictly connected with their structure. In the case of ensuring high compression strength, drainage systems made of synthetics are filled with aggregate. Another important aspect is the ability to retain water by the drainage layers. Studies carried out by BARYŁA et al. [2018a] on the influence of the type of drainage layer (washed gravel, kermesite, drainage mat) on the amount of retention showed, over the three-year course of studies, the highest retention in the model with the drainage mat. HAKIMDAVAR et al. [2014] determined the influence of the drainage layer on the reduction of the peak runoff wave and change in the time that the drainage of the rainfall occurs. Studies carried out by KARCZMARCZYK and KOCIK [2017] on the influence of the thickness of the reactive drainage layer $(1,2$ and $5 \mathrm{~cm}$ thickness) showed that the retention ability resulted mainly from the type of applied substrate, while the presence and thickness of the drainage layer did not have an influence on its changes. The small number of studies regarding the influence of the thickness and type of drainage layer on the retention ability of green roofs prompted the author to carry out studies in this scope. The article undertook the topic of using two mineral aggregates as the drainage layer on green roofs. The aim of the study was to: 1) determine if the drainage layer of a green roof is a significant factor influencing the retention of rainwater; 2) assessing the influence of the thickness of the drainage layer $(5,10 \mathrm{~cm})$ on the amount of retention on green roofs; and 3) revealing the differences in the retention abilities of two widely applied materials (Leca ${ }^{\circledR}$, quartzite grit) used as the drainage layer on green roofs.

\section{MATERIALS AND METHODS}

The influence of the thickness of the drainage layer on the amount of runoff was determined in a field experiment during the period 01.07-30.09.2018 (Fig. 1). Four columns with a diameter of $320 \mathrm{~mm}$ were filled with two types of drainage layer - lightweight expanded clay aggregate a)

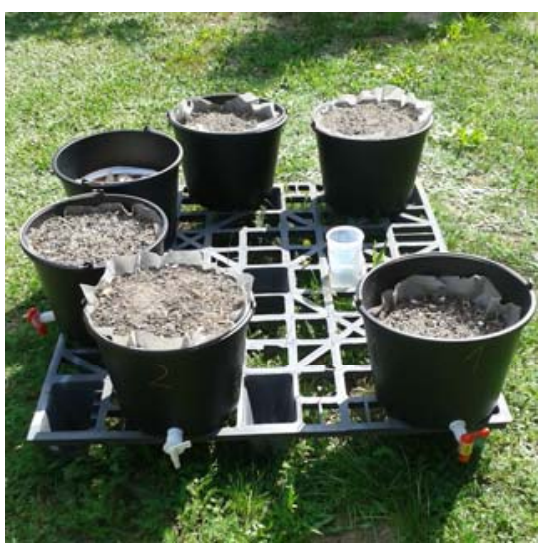

b)

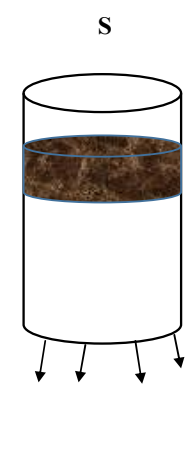

\section{RAINFALL}

SL1

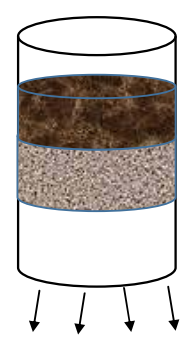

SL2

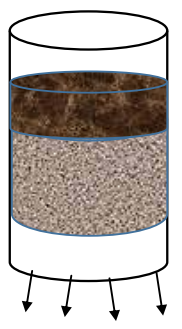

RUNOFF

Fig. 1. Diagram of test stands: a) view of test stand in field, b) diagram of test stands; $\mathrm{S}=$ intensive substrate, SL1 $=$ Leca ${ }^{\circledR}$ substrate with a thickness of $5 \mathrm{~cm}, \mathrm{SL} 2=$ Leca ${ }^{\circledR}$ substrate with a thickness of $10 \mathrm{~cm}, \mathrm{SG} 1=$ substrate and quartzite grit with a thickness $5 \mathrm{~cm}$, $\mathrm{SG} 2=$ substrate and quartzite grit with a thickness $10 \mathrm{~cm}$; source: own elaboration 
(Leca ${ }^{\circledR}$ Saint-Gobain Construction Products Polska sp. $\mathrm{Z}$ o.o.) and single-fraction mineral aggregate of quartzite grit. The Leca ${ }^{\circledR}$ is a lightweight construction material used in civil engineering, geoingineering, agriculture, horticulture and environmental protection [Leca undated]. One of the columns was filled with an intensive substrate and marked as S, two columns were filled with substrate as well as Leca ${ }^{\circledR}$ with a thickness of 5 and $10 \mathrm{~cm}$ and marked as SL1 and SL2 respectively, and two columns were filled with a substrate and quartzite grit, 5 and $10 \mathrm{~cm}$ in thickness, marked as SG1 and SG2 (see Table 1). A filtration layer was placed between the drainage layer and the substrate (polipropylene geotextile Polyfelt TS 20, endurance class GRK 2, weight of $0.125 \mathrm{~kg} \cdot \mathrm{m}^{-2}$ ).

The physical properties of aggregates were described in accordance with: particle size distribution PN-ISO 11277:2005, density PN EN 1097-3:2000, porosity PN-EN 1936:2010. The bulk density of the analysed aggregates was $1400\left(\mathrm{~kg} \cdot \mathrm{m}^{-3}\right)$ for the quartite grit, and $320\left(\mathrm{~kg} \cdot \mathrm{m}^{-3}\right)$ for Leca ${ }^{\circledR}$. Grain diameters for the quartzite grit ranged from $15 \mathrm{~mm}$ to $40 \mathrm{~mm}$, and for the Leca ${ }^{\circledR}$ aggregate from $4 \mathrm{~mm}$ to $10 \mathrm{~mm}$ respectively (see Table 2). For a drainage layer material the grain size is an important determinant of the water holding capacity [BEATTIE, BERGHAGE 2004]. The ability to permanently absorb water ie. the absorbability was also analyzed. From the point of view of green roof, the absorbability was more efficient for the Leca ${ }^{\circledR}$ $(18 \%)$, while the quartzite grit was very low at only $1 \%$.

Table 1. Physical characteristics of substrates used in the study

\begin{tabular}{|l|c|c|}
\hline Parameter & Unit & Value \\
\hline Content of fractions under $0.063 \mathrm{~mm}$ & $\%$ mass & 5 \\
\hline Content of fractions $0.05-2 \mathrm{~mm}$ & $\%$ mass & 65 \\
\hline Content of fractions $2-20 \mathrm{~mm}$ & $\%$ mass & 30 \\
\hline General porosity & $\%$ & $\geq 50$ \\
\hline Maximum water holding capacity & $\%$ & $\geq 35$ \\
\hline Organic matter content & $\%$ & 9 \\
\hline Water permeability mod. $K_{\text {fmod. }}$ & $\mathrm{mm} \cdot \mathrm{min}^{-1}$ & 5 \\
\hline Weight of substrate in moist state (bulk density) & $\mathrm{kg} \cdot \mathrm{m}^{-3}$ & 1350 \\
\hline $\begin{array}{l}\text { Weight of substrate in a state of complete water } \\
\text { saturation }\end{array}$ & $\mathrm{kg} \cdot \mathrm{m}^{-3}$ & 1700 \\
\hline Foreign matter content & $\%$ & $<0.1$ \\
\hline
\end{tabular}

Source: own study.

Table 2. Basic physical properties of the applied aggregates

\begin{tabular}{|l|c|c|c|}
\hline \multirow{2}{*}{ Physical properties } & \multirow{2}{*}{ Unit } & \multicolumn{2}{|c|}{ Aggregate } \\
\cline { 3 - 4 } & & quartzite grit & Leca $^{\circledR}$ \\
\hline Particle size & $\mathrm{mm}$ & $15-40$ & $4-10$ \\
\hline Dry density & $\mathrm{kg} \cdot \mathrm{m}^{-3}$ & $1400 \pm 15 \%$ & $320 \pm 15 \%$ \\
\hline Porosity & $\%$ & 40 & 48 \\
\hline Absorbability & $\%$ & 1 & 18 \\
\hline
\end{tabular}

Source: own study.

The granulometric composition of the substrate was described in accordance with PN-88/04481, water permeability, maximum water holding capacity, weight of the substrate in a state of full saturation with water, organic matter content, and foreign matter content were determined in accordance with DAFA [2015]. A fresh intensive substrate comprised of: compost, perlite, terraton, lava and crushed brick was used in the experiment.
The density of each substrate was $4 \mathrm{~cm}$; applying various thicknesses in individual test trays would have changed the retention abilities, making it more difficult to compare the results of the experiment. The volume of the runoff was measured by hand following each rainfall. The measurement of moisture content and temperature in the layer of the substrate was carried out using a WET-2 probe. The rainfall depth was measured next to the trays using a dish placed at the height of $1 \mathrm{~m}$. Based on the conventional approach involving the determination of atmospheric rainfalls, recommended and assumed in other "green-roof-type" studies, rainfall events divided every six or more hours and were classified as independent events [BERRETTA et al. 2014; GETTER et al. 2007; PALLA et al. 2012; SPEAK et al. 2013; STOVIN et al. 2012; 2013; VANWOERT et al. 2005; VOYDE et al. 2010]. Situations occurred, however, where the runoff from the previous event was still occurring when another event took place. In such cases, two adjacent "events" were combined into one. For each of these events, the retention of the green roof $(R \%)$ was determined. Runoff retention from the green roof was calculated as [ZHANG et al. 2015]:

$$
R=\frac{P-H}{P} \cdot 100 \%
$$

Where: $R=$ retention $(\%), P=$ precipitation $(\mathrm{mm})$ and $H=\operatorname{runoff}(\mathrm{mm})$.

The antecedent dry weather period (ADWP) or antecedent dry days, which is the duration of dry period prior to a precipitation event [ZHANG, GUO 2013] was calculated in hours. To identify an environmental factors that may have important role in green roof stormwater retention performance, multiple linear regression (MLR) was adopted for the statistical analysis. Three types of parameters were examined as explanatory variables to green-roof stormwater retention: rainfall, ADWP and soil moisture condition. Statistical analyses were carried out in the STATGRAPHICS Centurion XVI program.

\section{RESULTS OF STUDIES}

Over the course of 92 days during which the studies were carried out, each of the columns was supplied with $307.80 \mathrm{~mm}$ in the form of atmospheric and simulated precipitation (see Table 3 ). In this period, 21 rainfall events occurred, of which 12 events did not exceed $10 \mathrm{~mm}$, the maximum dose was $53.10 \mathrm{~mm}$, with the minimal being 1.9 $\mathrm{mm}$. Based on the average value of retention of total rainfalls for all simulated rainfall events, the sequence of maintaining rainfalls was similar S (47.6\%) SL1 (57.0\%) SL2 $(61.3 \%)$ SG1 (50.1\%) SG2 (52.9\%). An analysis of the relationships between rainfalls and retention ability showed that the linear model explains form 16 to $30 \%$ variance in retention ability in the rainfall function (Fig. 2a). The ANOVA analysis of variance showed that statistically significant differences do not exist between the groups of retention results for the individual columns $F_{(4,100)}=0.48$; $p>0.05$. The additionally performed Mood's median test did not show statistically significant differences between the groups $p>0.05$ (Fig. 2b). 
Table 3. Experimental data of column leaching experiment

\begin{tabular}{|c|c|c|c|c|c|}
\hline Substrate & $\mathrm{S}$ & SL1 & SL2 & SG1 & SG2 \\
\hline Volume of leachate $Q(\mathrm{~mm})$ & 307.82 & 307.82 & 307.82 & 307.82 & 307.82 \\
\hline Retention $R(\%)$ : mean (min $-\max )$ & $\begin{array}{c}47.60 \\
(0.43-100)\end{array}$ & $\begin{array}{c}57.00 \\
(3.23-100)\end{array}$ & $\begin{array}{c}61.31 \\
(10.06-100)\end{array}$ & $\begin{array}{c}50.10 \\
(2.24-100)\end{array}$ & $\begin{array}{c}52.86 \\
(5.58-100)\end{array}$ \\
\hline Moisture (\%): mean (min-max) & $\begin{array}{c}14.32 \\
(3.0-27.0)\end{array}$ & $\begin{array}{c}12.72 \\
(3.0-25.6)\end{array}$ & $\begin{array}{c}12.44 \\
(2.1-26.6)\end{array}$ & $\begin{array}{c}12.72 \\
(3.0-25.6)\end{array}$ & $\begin{array}{c}12.62 \\
(3.0-25.0)\end{array}$ \\
\hline Substrate temperature $T\left({ }^{\circ} \mathrm{C}\right)$ : mean $(\min -\max )$ & $\begin{array}{c}25.81 \\
(19.6-32.7)\end{array}$ & $\begin{array}{c}24.17 \\
(19.6-31.5)\end{array}$ & $\begin{array}{c}24.74 \\
(19.0-32.5)\end{array}$ & $\begin{array}{c}24.57 \\
(18.8-33.2)\end{array}$ & $\begin{array}{c}24.42 \\
(18.7-33.4)\end{array}$ \\
\hline
\end{tabular}

Explanations: S, SL1, SL2, SG1, SG2 as in Fig. 1.

Source: own study.

Similarity to studies regarding the retention ability of green roofs and retention ability of substrates [BARYŁA et al. 2018b], decreases along with an increase in the rainfall depth (Fig. 3]. The obtained negative values of correlation S (-0.47), SL1 (-0.46), SL2 (-0.54), SG1 (-0.45), SG2 $(-0.48)$ for $p<0.05$ showed an average relationship between rainfall depth $(\mathrm{mm})$ and the retention ability of the columns. In studies by PALLA et al. [2010], during ten months, data containing 30 individual rainfall events were obtained, where the average retention amounted to $51.5 \%$. Eleven events exceeding $40 \mathrm{~mm}$ in depth occurred, and the total controlled amount of rainfall was $1165.1 \mathrm{~mm}$. The obtained retention gave the basis for suggesting that this is proof of excellent results of controlling rainwater. However, from the perspective of drainage engineering, the average retention per rainfall event can be of less meaning than understanding the general yearly retention of a system or its reaction to extreme events. The presented data show that in the case of many greater events, retention was in fact lower than $25 \%$. Because these greater events comprise the majority of total rainfalls, the total volume retained was approximately $35 \%$. A yearly retention efficiency of e.g. $60 \%$ should not be used to conclude that the roof will be able to retain $60 \%$ or even $30 \%$ of a significant rainfall. Similarly, there are many different roof configura-

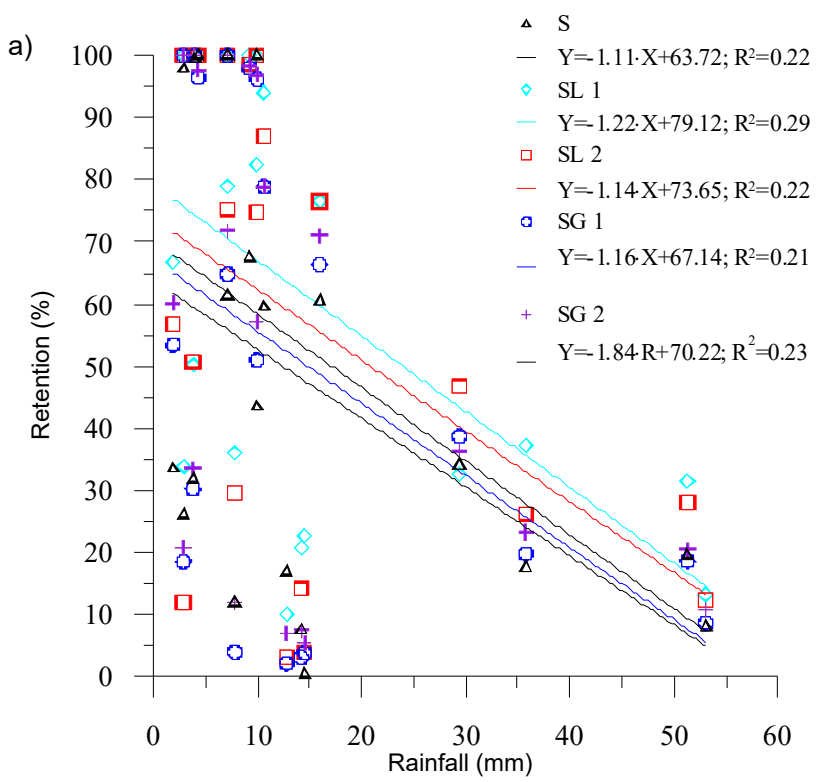

tions (type and thickness of the substrate, slope, size, method of planting), from which we can expect that they will differ, and the same roof configuration will not show the same characteristics of efficiency in two different climatic conditions. Some Authors suggest, that regional climatic conditions are significant factors influencing green roof retention [BERRETTA et al. 2014; VOYDE et al. 2010]. At the local scale microclimatic conditions may differ between the roofs due to specific site condition

The next factor analysed in the retention of green roofs are the starting conditions prior to the occurrence of a rainfall antecedent dry weather period (ADWP) [ZHANG, GUO 2013]. Studies carried out by BURSZTA-ADAMIAK et al. [2014] showed that retention increases along with an increase in the number of rainless days. In the cited work, as little as one rainless day led to improved retention ability of the green roof. In studies carried out by KARCZMARCZYK and KOCIK [2017], such relationship was not observed. In the carried out studies it was shown that, along with an increase in the (ADWP), retention ability increases (Fig. 3). The obtained values of correlation SL2 (0.44), SL1 (0.36), SG1 (0.42), SG2 (0.42) for $p<0.05$ showed an average correlation between ADWP $(\mathrm{h})$ and the retention ability of columns (Fig. 3a).

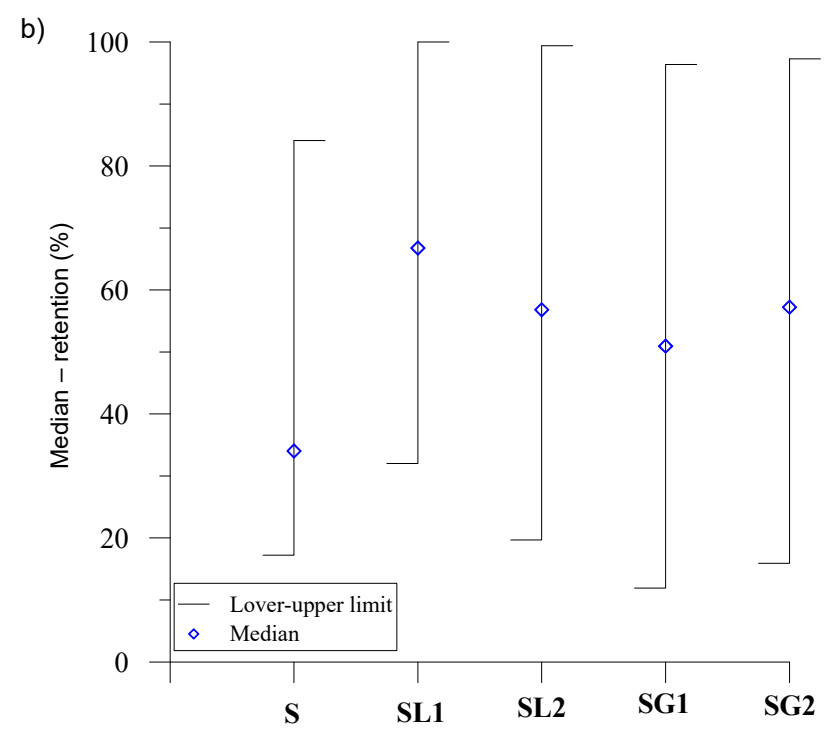

Fig. 2. Relationship between retention $R(\%)$ and rainfalls $P(\mathrm{~mm})$, as well as in columns with Mood's interval at $95 \%$ level of confidence; S, SL1, SL2, SG1, SG2 as in Fig. 1; source: own study 

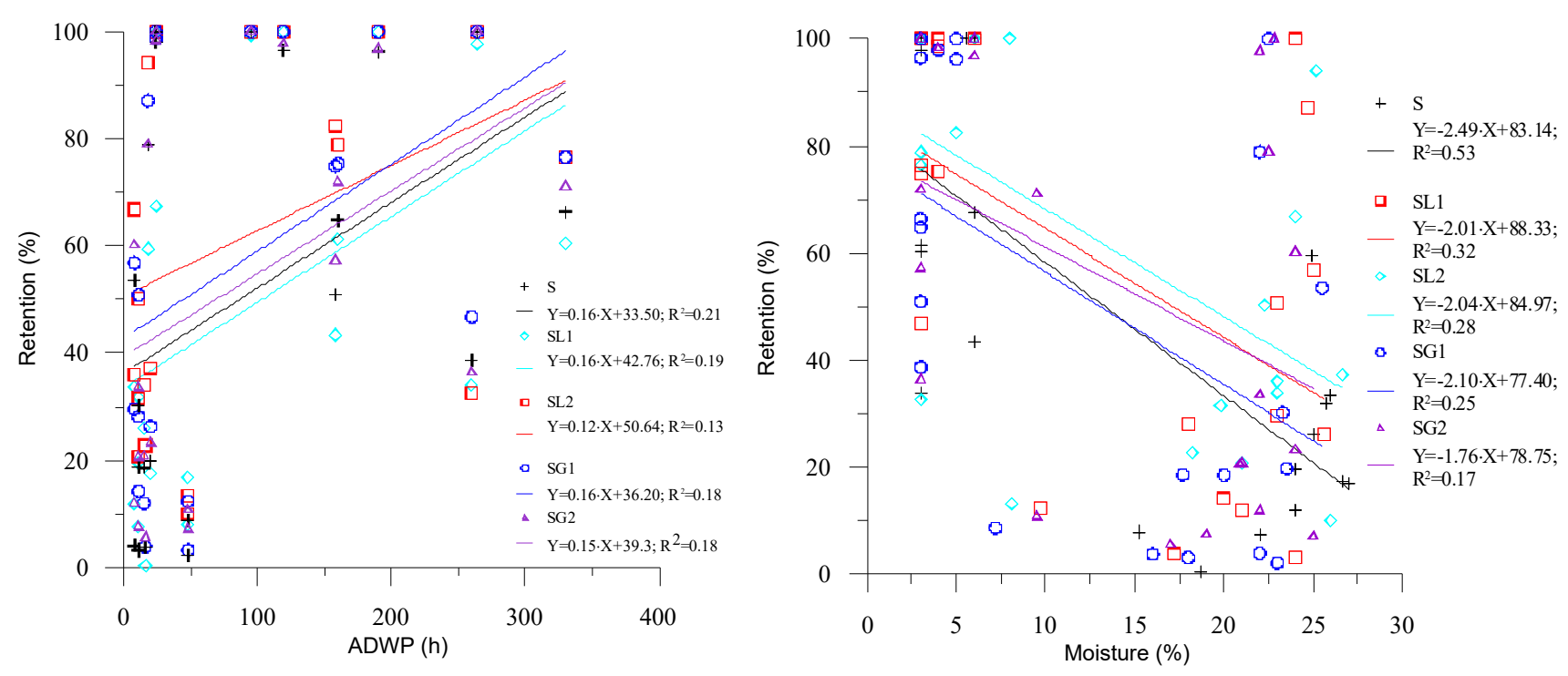

Fig. 3. Relationship between retention $(R)$ and: a) antecedent dry weather period (ADWP), b) moisture content; S, SL1, SL2, SG1, SG2 as in Fig. 1; source: own study

In the case of initial moisture content, the regression coefficients indicate that, along with an increase in initial moisture content, the retention ability of the trays decreases. The obtained negative results of correlation in a linear relationship between retention and moisture content were higher than in the in the relationship between retention and rainfall depth (Fig 3b). The calculated correlation coefficients in the linear relationship between retention and moisture content were S(-0.73), SL1 (-0.53), SL2 (-0.57), SG1 $(-0.50)$ and SG2 $(-0.44)$, which signifies an average relationship. For each pair of variables, statistically significant linear correlations were shown at a 5\% level of significance.

The results shoved, that volume of precipitation, moisture substrate, ADWP have a significant effect on green roof retention. The obtained data show that the value of retention decreases with increasing rainfall and substrate moisture, while the ADWP increases the green roofs retention ability. Performed statistical analysis confirmed that rainfall depth and moisture substrate are strongly correlated with retention. Similar results are also reported by UHL and SChIEDT [2008], StOvin et al. [2015], PALla et al. [2010], SIMS et al. [2016], and SoULIS et al. [2017].

\section{SUMMARY AND CONCLUSIONS}

The drainage layer is one of the factors influencing the hydrological efficiency of green roofs. It is also an important structural element of such roofs due to the effects of inappropriate selection or construction of the layer. One of these are disturbances in the drainage of water infiltrated by the soil substrate or road base. Constantly occurring puddles or soaked soil substrate may indicate improper drainage, as well as plants dying or showing signs of disease. In the event of intense rainfalls, this can even lead to partial inundation or flooding on the green roof. A wet soil substrate is moreover the perfect habitat for mould and fungus. Over the course of carrying out the studies, longstanding water was not observed on the surface, which sig- nifies good permeability of the substrate as well as the drainage layers. The average ability to retain rainwater in all columns ranged from $50-60 \%$, which is in agreement with the retention ability of green roofs without vegetation cover (60\%) given by HARPER et al. [2015]. The retention of the substrate was $48 \%$; for a $5 \mathrm{~cm}$ drainage layer of Leca $^{\circledR}, 10 \%$ higher retention was obtained, while a $10 \mathrm{~cm}$ layer resulted in $14 \%$ higher retention. Smaller differences of the retention value between the substrate and the substrate with drainage layers were noted for quartzite grit. For a $5 \mathrm{~cm}$ layer, the difference was $3 \%$, whereas for the 10 centimetre thickness $-5 \%$. The obtained differences between the two aggregates in the retention of rainwater stem from the absorbency of aggregates (Leca ${ }^{\circledR} 18 \%$, grit $1 \%)$. Faster drying of the substrate with the drainage layer was observed as compare to the tray without the drainage layer. Differences in the individual trays were not significant. It was observed that the amount of rainfall is a factor influencing the amount of water retained on a green roof, which confirms studies carried out by many authors. The initial state of the moisture content of a green roof substrate appears to be a significant factor in reducing the runoff or rainwater from a green roof, as the obtained results pointed to a higher correlation of retention with moisture content than with the ADWP.

\section{REFERENCES}

Atallah M., Hazzab A., Seddini A., Ghenaim A., Korichi K. 2018. Inundation maps for extreme flood events: Case study of Sidi Bel Abbes city, Algeria. Journal of Water and Land Development. No. 37 p. 19-27. DOI 10.2478/jwld-20180021.

Banting D., Doshi H., Li J., Missios P. 2017. Report on the benefits and costs of green roof technology for the city of Toronto [online]. [Access 10.10.2017]. Available at: https://web. toronto.ca/wp-content/uploads/2017/08/8f39-Report-on-theEnvironmental-Benefits-and-Costs-of-Green-RoofTechnology-for-the-City-of-Toronto-Full-Report.pdf 
BaryŁa A., KarczmarczyK A., Brandyk A., Bus A. 2018a. The influence of a green roof drainage layer on retention capacity and leakage quality. Water Science and Technology. Vol. 77. Iss. 12 p. 2886-2895. DOI 10.2166/wst.2018.283.

BARYŁa A., KARCZMARCZYK A., Bus A. 2018b. Role of substrates used for green roofs in limiting rainwater runoff. Journal of Ecological Engineering. Vol. 19. Iss. 5 p. 86-92.

BARSZCZ M. 2016. Analysis of probable flows based on the rainfall-runoff model for flood scenarios: A case study of the Losse River catchment (Germany). Polish Journal of Environmental Studies. Vol. 25. No. 4 p. 1403-1413.

Beattie D., Berghage R. 2004. Green roof media characteristics: The basics [The 7th annual greening rooftops for sustainable communities conference]. [2-4.07.2004 Portland].

BengtsSON L., GraHn L., OlsSON J. 2005. Hydrological function of a thin extensive green roof in southern Sweden. Nordic Hydrology. Vol. 36. Iss. 3 p. 259-268.

BERNDTSSON J.C. 2010. Green roof performance towards management of runoff water quantity and quality: A review. Ecological Engineering. Vol. 36 p. 351-360.

BerRetTA C., PoË S., STOVIn V. 2014. Moisture content behavior in extensive green roofs during dry periods: The influence of vegetation and substrate characteristics. Journal of Hydrology. Vol. 511 p. 374-386.

Boas Berg A., RadziemsKa M., AdAmcová D., Vaverková M.D. 2017. Green roofs as an alternative solution to reduced green surface area in highly urbanized cities of the European Union - the study case of the Netherlands. Acta Scientiarum Polonorum. Architectura. Vol. 16. Iss. 4 p. 59-70. DOI 10.22630/ASPA. 2017.16.4.06.

Buffam I., Mitchell M.E., DuRTSChe R.D. 2016. Environmental drivers of seasonal variation in green roof water quality. Ecological Engineering. Vol. 91 p. 506-514.

BurSZTA-ADAMIAK E., ŁOMOTOWSKI J.I, WiERCIK P. 2014. Zielone dachy jako rozwiązania poprawiające gospodarkę wodami opadowymi w miastach [Green roofs as a tool for improvement the stormwater management in urban areas]. Inżynieria Ekologiczna. Nr 39 p. 26-32.

Bus A., KARCZMARCZYK A., BARYŁA A. 2016. The use of reactive material for limiting p-leaching from green roof substrate. Water Science and Technology. Vol. 73. Iss. 12 p. 3027-3032. DOI 10.2166/wst.2016.173.

Catalano C., Laudicina V.A., Badalucco L., Guarino R. 2018. Some European green roof norms and guidelines through the lens of biodiversity: Do ecoregions and plant traits also matter? Ecological Engineering. Vol. 115 p. 15-26.

DAFA 2015. Dachy zielone. Wytyczne do projektowania, wykonywania i pielęgnacji dachów zielonych - wytyczne dla dachów zielonych [Guidelines for designing, constructing and caring for green roofs - guidelines for green roofs]. Opole, Poland. Stowarzyszenie Wykonawców Dachów Płaskich i Fasad (DAFA) pp. 84.

EMIlsson T., CzEMIEL BeRndTSSON J., MATTSSON J.E., Rolf K. 2007. Effect of using conventional and controlled release fertiliser on nutrient runoff from various vegetated roof systems. Ecological Engineering. Vol. 29. Iss. 3 p. 260-271. DOI 10.1016./j.ecoleng.2006.01.001.

Getter K.L., Rowe D.B., ANDRESEn J.A. 2007. Quantifying the effect of slope on extensive green roof stormwater retention. Ecological Engineering. Vol. 31. Iss. 4 p. 225-231. DOI 10.1016/j.ecoleng.2007.06.004.

Hakimdavar R., Culligan P.J., Finazzi M., Barontini S.I., RANZI R. 2014. Scale dynamics of extensive green roofs: quantifying the effect of drainage area and rainfall characteristics on observed and modeled green roof hydrologic performance. Ecological Engineering. Vol. 73 p. 494-508. DOI 10.1016/j.ecoleng.2014.09.080.
KARCZMARCZYK A., KociK A. 2017. Wpływ miąższości reaktywnej warstwy drenażowej na odpływ fosforanów z zielonego dachu [Influence of the thickness of the P-reactive drainage layer on phosphate content in green roof runoff]. Przegląd Naukowy - Inżynieria i Kształtowanie Środowiska. Nr 26 (4) p. 447-456. DOI 10.22630/PNIKS.2017.26.4.43.

KÖHLER M. 2006. Long-term vegetation research on two extensive green roofs in Berlin. Urban Habitats. No. 4 p. 3-26.

Leca $^{\circledR}$ undated. Keramzyt [Expanded clay] [online]. [Access 10.10.2017]. Available at: http://leca.pl/produkty

Morgan S., CeliK S., RETZ W. 2013. Green roof stormwater runoff quantity and quality. Journal of Environmental Engineering. Vol. 139. Iss. 4 p. $471-478$.

MrowIEC M., SOBCZYK M. 2014. Ekologiczne zagospodarowanie wód opadowych - zielone dachy [Ecological management of rainwaters - green roofs]. Woda-Środowisko-Obszary Wiejskie. T. 14. Z. 4(48) s. 53-61.

Palla A., Gnecco I., LANZA L.G. 2010. Hydrologic restoration in the urban environment using green roofs. Water. Vol. 2 p. 140-154. DOI 10.3390/w2020140.

Palla A., GnecCo I., LANZA L.G. 2012. Compared performance of a conceptual and a mechanistic hydrologic models of a green roof. Hydrological Processes. Vol. 26 p. 73-84.

Pęczkowski G., Kowalczyk T., SZawernoga K., OrZepowski W., ŻMudA R., POKŁADEK R. 2018. Hydrological performance and runoff water quality of experimental green roofs. Water. Vol. 10 (1185) pp. 15.

PN-EN 1097-3:2000 Badania mechanicznych i fizycznych właściwości kruszyw - Oznaczanie gęstości nasypowej i jamistości [Tests of mechanical and physical properties of aggregates - Determination of loose bulk density and voids].

PN-EN 1936:2010 Metody badań kamienia naturalnego - Oznaczanie gęstości i gęstości objętościowej oraz całkowitej i otwartej porowatości [Methods of testing natural stone Determination of density and bulk density as well as total and open porosity].

PN-EN 13242 Kruszywa do niezwiązanych i związanych hydraulicznie materiałów stosowanych w obiektach budowlanych i budownictwie drogowym [Aggregates for unbound and hydraulically bound materials used in buildings and road construction].

PN-ISO 11277:2005 Jakość gleby - Oznaczanie składu granulometrycznego w mineralnym materiale glebowym - Metoda sitowa i sedymentacyjna [equivalent to ISO 11277:2009 Soil quality - Determination of particle size distribution in mineral soil material - Method by sieving and sedimentation].

RomaniaK A. 2017. Assesment of the relation between atmospheric precipitation and rainwater runoff for various urban surfaces. Journal of Water and Land Development. No. 32 p. 87-94. DOI 10.1515/jwld-2017-0010.

Sims A., Robinson C., SMART C., VoOgt J., Hay G., Lundholm J., Powers B., O'CARroll D. 2016. Retention performance of green roofs in three different climate regions. Journal of Hydrology. Vol. 542 p. 115-124.

SOBCZYK M., MrowIEC M. 2016. Retention capacity of extensive green roofs. Journal of Water and Land Development. No. 30 p. 113-117. DOI 10.1515/jwld-2016-0027.

Soulis K., Ntoulas N., NekTarios P., Kargas G. 2017. Runoff reduction from extensive green roofs having different substrate depth and plant cover. Ecological Engineering. Vol. 102 p. $80-89$.

SpeAK A.F., Rothwell J.J., LindLey S.J., SMith C.L. 2013. Rainwater runoff retention on an aged intensive green roof. Science of the Total Environment. Vol. 461-462 p. 28-38.

Stovin V., POË S., BerRetTA C. 2013. A modelling study of long term green roof retention performance. Journal of Environmental Management. Vol. 131 p. 206-215. 
Stovin V., Poe S., DeVille S., Berretta C. 2015. The influence of substrate and vegetation configuration on green roof hydrological performance. Ecological Engineering. Vol. 85 p. $159-172$.

Stovin V., Vesuviano G., Kasmin H. 2012. The hydrological performance of a green roof test bed under UK climatic conditions. Journal of Hydrology. Vol. 414-415 p. 148-161.

Szota C., Farrell C., Williams N., Arndt S., Fletcher T. 2017. Drought-avoiding plants with low water use can achieve high rainfall retention without jeopardising survival on green roofs. Science of the Total Environment. Vol. 603604 p. $340-351$.

SZULCZEWSKa B., GIERDYCH R., Borowski J., KUCHCIK M., SIKORSKI P., MAZURKIEWICZ A., STAŃCZYK T. 2014. How much green is needed for a vital neighbourhood? in search for empirical evidence. Land Use Policy. Vol. 38 p. 330-345.

UhL M., Schiedt L. 2008. Green roof storm water retention: monitoring results. [11th International Conference on Urban Drainage]. [31.08-5.09.2008 Edinburgh, Scotland].

VanWoert N.D., Rowe D.B., Andresen J.A., Rugh C.L., FerNANDEZ R.T., XIAO L. 2005. Green roofs stormwater reten- tion: effects of roof surface, slope, and media depth. Journal of Environmental Quality. Vol. 34 p. 1036-1044.

VillarReal E., BengtSSON L. 2005. Response of a sedum greenroof to individual rain events. Ecological Engineering. Vol. 25. Iss. 1 p. 1-7.

Voyde E., FAsSman E., Simcock R. 2010. Hydrology of an extensive living roof under sub-tropical climate conditions in Auckland, New Zealand. Journal of Hydrology. Vol. 394 p. 384-395.

WONG G., JIM W. 2015. Identifying keystone meteorological factors of green-roof storm water retention to inform design and planning. Ecological Engineering. Vol. 85 p. 159-172.

Zhang Q., Miao L., Wang X., Liu D., Zhu L., Zhou B., Sun J., LIU J. 2015. The capacity of greening roof to reduce storm water runoff and pollution. Landsc. Urban Plan. Vol. 144 p. 142 150.

ZHANG S. GuO Y. 2013. Analytical probabilistic model for evaluating the hydrologic performance of green roofs. Journal of Hydrologic Engineering. Vol. 18 p. 19-28.

\section{Anna M. BARYLA}

\section{Rola warstwy drenażowej na zielonych dachach w ograniczaniu odpływu wód opadowych $\mathrm{z}$ terenów zurbanizowanych}

\section{STRESZCZENIE}

Istotną rolę w zrównoważonych systemach drenażu odgrywają zielone dachy. Są powierzchniami chłonnymi w odniesieniu do wód opadowych, które retencjonują w profilu i za pomocą roślin. Biorą zatem czynny udział w poprawie warunków klimatycznych miasta, a szerzej bilansu wodnego terenów zurbanizowanych. Jednym z czynników wpływających na wydajność hydrologiczną zielonych dachów jest warstwa drenażowa. W artykule przedstawiono wyniki badań kolumnowych przeprowadzonych w warunkach polowych, w których porównano retencyjność dwóch kruszyw wykorzystywanych jako warstwa drenażowa na zielonych dachach - keramzytu i grysu kwarcytowego. Średnia retencja substratu wyniosła wyniosła $48 \%$, dla $5 \mathrm{~cm}$ warstwy drenażowej z Leca ${ }^{\circledR}$ wyniosła $57 \%$, dla warstwy $10 \mathrm{~cm}$ średnia retencja wyniosła $61 \%$. Dla grysu kwarcytowego średnia retencja wyniosła dla $5 \mathrm{~cm}$ warstwy drenażowej $50 \%$, dla $10 \mathrm{~cm}$ warstwy drenażowej 53\%. Największą retencję uzyskano w kolumnie z substratem i 10-centymetrową warstwą keramzytu. Wykazano, że keramzyt jest lepszym materiałem retencyjnym niż grys kwarcytowy. Początkowy stan wilgotności podłoża z zielonego dachu wydaje się być istotnym czynnikiem w redukcji odpływu wód opadowych z dachu zielonego. Uzyskane wyniki wilgotności początkowej dały silniejszą korelację niż czas pomiędzy opadami

Słowa kluczowe: odplyw, retencja, warstwa drenażowa, zielony dach 